\title{
Valorization of a Pulp Industry By-Product through the Production of Short-Chain Organic Acids
}

\author{
Diogo Queirós, Rita Sousa, Susana Pereira and Luísa S. Serafim * \\ CICECO-Aveiro Institute of Materials, Chemistry Department, University of Aveiro, \\ Campus Universitário de Santiago, 3810-193 Aveiro, Portugal; dc.queyros@gmail.com (D.Q.); \\ sousa.rita@ua.pt (R.S.); susana.raquel@ua.pt (S.P.) \\ * Correspondence: luisa.serafim@ua.pt; Tel.: +351-234-370-360
}

Academic Editor: Gunnar Lidén

Received: 8 February 2017; Accepted: 8 May 2017; Published: 12 May 2017

\begin{abstract}
In this work, hardwood sulfite spent liquor (HSSL)—a by-product from a pulp and paper industry-was used as substrate to produce short-chain organic acids (SCOAs) through acidogenic fermentation. SCOAs have a broad range of applications, including the production of biopolymers, bioenergy, and biological removal of nutrients from wastewaters. A continuous stirred tank reactor (CSTR) configuration was chosen to impose selective pressure conditions. The CSTR was operated for 88 days at $30^{\circ} \mathrm{C}$, without $\mathrm{pH}$ control, and 1.76 days of hydraulic and sludge retention times were imposed. The culture required 46 days to adapt to the conditions imposed, reaching a pseudo-steady state after this period. The maximum concentration of SCOAs produced occurred on day $71-7.0 \mathrm{~g}$ carbon oxygen demand (COD)/L that corresponded to a degree of acidification of $36 \%$. Acetate, propionate, butyrate, valerate, and lactate were the SCOAs produced throughout the 88 days, with an average proportion of 59:17:19:1.0:4.0\%, respectively.
\end{abstract}

Keywords: short-chain organic acids; hardwood sulfite spent liquor; activated sludge; acidogenic fermentation; mixed microbial cultures

\section{Introduction}

The increasing interest in new renewable sources of energy and materials is a consequence of several factors, including the rapid depletion of petroleum and the colossal generation of residues and wastes-both direct consequences of human population growth and its activities. To exploit the potential of using wastes as feedstock, waste management needs to move from treatment-oriented processes to the integration of technologies able to valorize organic waste streams for the production of value-added products [1,2].

Currently, a considerable effort is being made to develop technologies that are able to produce value-added products using residues and by-products. Koutinas et al. [3] enlisted several compounds to be produced from wastes: building-blocks such as succinic acid, 2,3-butanediol, and 1,3-propanediol; biofuels like bioethanol and biohydrogen; and polymers such as bacterial cellulose and polyhydroxyalkanoates (PHAs); and short-chain organic acids (SCOAs) [3].

SCOA production is currently achieved by chemical synthesis, followed by distillation at atmospheric pressure [2]. These compounds have a maximum of six carbon atoms, and present a broad range of applications in the production of biopolymers [4,5], bioenergy [6], and the biological removal of nutrients from wastewaters [4,7].

Organic industrial and urban wastes can act as substrate for SCOA production through acidogenic fermentation (AF). This is a stage of anaerobic digestion (AnD) where several organic compounds present in wastes are transformed into SCOAs including acetate, propionate, butyrate, or lactate, and alcohols such as ethanol [8]. AnD is a complex process which can be divided into four individual 
stages: hydrolysis, acidogenic fermentation, acetogenesis, and methanogenesis. If AF is the objective, the process should be interrupted at acidogenesis or acetogenesis by inhibiting methanogenesis. AnD is a mature technology that is usually employed worldwide within full-scale facilities for the treatment of industrial and urban wastewaters and organic solid wastes. AnD is advantageous over aerobic activated sludge systems because of its high organic content removal, low energy input requirements, energy production, and low sludge production [9]. Usually, the final goal of AnD is the production of methane and carbon dioxide (biogas), and only recently is being driven by the formation of SCOAs. For SCOA production, it is essential to establish selective pressure conditions to inhibit methanogenic microorganisms and select those which are capable of synthesizing SCOAs, maximizing their production [10]. This selection is possible because methanogenic microorganisms are quite sensitive to operational conditions like temperature, or to the presence of inhibitors, and usually present low growth rates compared to the acidogenic population [11]. Furthermore, the thermodynamics of $\mathrm{AF}$ is more favorable than methanogenesis $[8,12]$.

AF has the potential to produce value-added compounds from low-cost waste-based materials. This aspect is of vital importance to the integration of an AF stage into other processes, once the substrate costs often contribute significantly to the overall process economy. Therefore, there are critical parameters to be ascertained to select the most suitable waste streams for acidogenic fermentation, and thus to establish a more cost-effective process. These include the biochemical acidogenic potential of the waste stream, which is the composition and amount of SCOAs that can be generated from the fermentation of the organic wastes [2]. Generated SCOAs can be used further in other processes; namely, the production of PHAs by mixed microbial cultures (MMCs) [13,14]. Parameters such as $\mathrm{pH}[15,16]$, temperature [15], hydraulic retention time (HRT), solids retention time (SRT) [17,18], and organic loading rate (OLR) [19] have already been studied in the production of SCOA from industrial or municipal wastes.

The objective of this work was to evaluate the possibility of the application of AF to hardwood sulfite spent liquor (HSSL) —an industrial by-product from the pulp and paper industry-to produce SCOAs. Sulfite spent liquors have the potential to be valorized through a lignocellulosic biorefinery approach [20]. Due to the considerable amount of sugars such as glucose, xylose, and in smaller amounts, galactose, mannose, and arabinose, SCOA production is a strong opportunity to be explored. Instead of using the traditional anaerobic sludge as the inoculum of the process, an aerobic activated sludge was chosen and submitted to anaerobic conditions without $\mathrm{pH}$ control and temperature-controlled at $30^{\circ} \mathrm{C}$. This procedure was expected to inhibit the presence of methanogenic bacteria and increase the presence of the acidogenic population [11,21].

\section{Materials and Methods}

\subsection{Microbial Culture}

The reactor was inoculated with an MMC collected from an aerobic tank of the wastewater treatment plant (WWTP) Aveiro Sul, SIMRia. The inoculum concentration was $10.5 \mathrm{~g}$ carbon oxygen demand $(\mathrm{COD}) / \mathrm{L}$.

\subsection{Experimental Setup}

A continuous stirred tank reactor (CSTR) configuration was chosen to perform the AF of chemically pre-treated HSSL under anaerobic conditions. The working volume of the reactor was $1.55 \mathrm{~L}$, and the flow rate of the feeding solution was $0.85 \mathrm{~L} /$ day, resulting in a hydraulic retention time (HRT) of 1.76 days. The reactor had no retention system for the biomass, resulting in a SRT similar to the HRT. The effluent was collected at the outlet of the reactor by overflow. Reactor stirring was performed by a magnetic stirrer and kept constant at $100 \mathrm{rpm}$. Nitrogen was sparged regularly to assure anaerobic conditions. Oxidation-reduction potential (ORP) was monitored with a transmitter M300 2-channel ORP meter (Mettler-Toledo Thornton, Inc., Greifensee, Switzerland). The system worked with temperature control at $30.1 \pm 1.0^{\circ} \mathrm{C}$ and without $\mathrm{pH}$ control. 


\subsection{Substrate}

HSSL from magnesium-based acidic sulfite pulping of Eucalyptus globulus was supplied by Caima-Indústria de Celulose S.A. (Constância, Portugal). Pre-evaporated HSSL was collected from an inlet evaporator from a set of multiple-effect evaporators to avoid the presence of free $\mathrm{SO}_{2}$. To remove part of the most recalcitrant compounds, HSSL was submitted to a preliminary pretreatment [22]. The pretreatment started with a $\mathrm{pH}$ adjustment to 7.0 with $6 \mathrm{M} \mathrm{KOH}$, followed by aeration with compressed air ( $2880 \mathrm{~L}$ of compressed air per liter of HSSL in $6 \mathrm{~h}$ ). Then, the liquor was centrifuged for $1 \mathrm{~h}$ at $5000 \mathrm{rpm}$. The precipitated colloids were filtered using a $1 \mu \mathrm{m}$ glass microfiber filter. Finally, the pre-treated HSSL was stored at $4{ }^{\circ} \mathrm{C}$. The total carbon oxygen demand (COD) of pretreated HSSL was determined $(\approx 267 \mathrm{~g} C O D / \mathrm{L})$. Lignosulphonates $(\mathrm{LS})$ and phenolic components were still the main constituents (ca. $190 \mathrm{~g} / \mathrm{L}$ ), along with xylose, acetate, and glucose (43.5, 14.4, and $7.9 \mathrm{~g} / \mathrm{L}$, respectively). No phosphates or ammonia were detected in the HSSL.

\subsection{Fermentation Medium}

To achieve an organic load rate (OLR) of $11.8 \mathrm{~g}$ COD/L day in the CSTR, HSSL was diluted with a mineral solution at a ratio of 1:12.8 (v:v). The mineral solution was composed by (per liter of distilled water): $80 \mathrm{mg}$ of $\mathrm{CaSO}_{4} \cdot 2 \mathrm{H}_{2} \mathrm{O}, 160 \mathrm{mg}$ of $\mathrm{FeSO}_{4} \cdot 7 \mathrm{H}_{2} \mathrm{O}, 160 \mathrm{mg}$ of $\mathrm{MgSO}_{4} \cdot 7 \mathrm{H}_{2} \mathrm{O}, 80 \mathrm{mg}$ of $\mathrm{Na}_{2} \mathrm{MoO}_{4} \cdot 2 \mathrm{H}_{2} \mathrm{O}, 160 \mathrm{mg}$ of $\mathrm{NH}_{4} \mathrm{Cl}$. The $\mathrm{pH}$ of the medium was adjusted to 7.0 , and the medium was autoclaved for $20 \mathrm{~min}$ at $121^{\circ} \mathrm{C} . \mathrm{KH}_{2} \mathrm{PO}_{4}(160 \mathrm{mg} / \mathrm{L})$ and $\mathrm{K}_{2} \mathrm{HPO}_{4}(80 \mathrm{mg} / \mathrm{L})$ were added under sterile conditions.

\subsection{Sampling}

Samples were collected every 4 days, three times a day, at intervals of $3 \mathrm{~h}$ (sample volume of $5 \mathrm{~mL}$ ). Samples were further centrifuged at 13,000 rpm for $10 \mathrm{~min}$, the pellet discarded, and the $\mathrm{pH}$ of the supernatant measured before storage under $-16^{\circ} \mathrm{C}$ for later determination of glucose, xylose, SCOAs, COD, and LS concentrations. Five milliliter samples were regularly collected for the determination of total suspended solids (TSS) and volatile suspended solids (VSS).

\subsection{Analytical Methods}

Biomass concentration was determined using total suspended solids (TSS) and volatile suspended solids (VSS) procedure described in Standard Methods [23]. Microfiber filters with $1.0 \mu \mathrm{m}$ pore size were calcined for $30 \mathrm{~min}$ at $550^{\circ} \mathrm{C}$ to remove all organic matter. After cooling to room temperature, filters were weighed, and $5.0 \mathrm{~mL}$ samples were filtered. Then, filters with the biomass were dried in the oven for $24 \mathrm{~h}$ at $105{ }^{\circ} \mathrm{C}$ to remove water and were then weighed at room temperature to achieve the TSS concentrations. Finally, the filters were calcined at the same conditions as earlier, and finally weighed at room temperature to achieve the VSS concentrations.

COD was measured accordingly to Standard Methods [23]. Replicates were prepared for each sample, which were diluted according to the detection range of the method (100-900 $\mathrm{mg} / \mathrm{L}$ ). Diluted sample $(2.0 \mathrm{~mL})$ was mixed with $2.8 \mathrm{~mL}$ of digestion solution $\left(20.43 \mathrm{~g}\right.$ of $\mathrm{K}_{2} \mathrm{Cr}_{2} \mathrm{O}_{7}, 66.6 \mathrm{~g}$ of $\mathrm{HgSO}_{4}$, $334 \mathrm{~mL}$ of $\mathrm{H}_{2} \mathrm{SO}_{4}$ in $2 \mathrm{~L}$ of distilled water) and $1.2 \mathrm{~mL}$ of acidic solution $\left(23.3 \mathrm{~g}\right.$ of $\mathrm{AgSO}_{4}$ in $2 \mathrm{~L}$ of $\mathrm{H}_{2} \mathrm{SO}_{4}$ ). In the preparation of blank, $2.0 \mathrm{~mL}$ of distilled water was added to the test tubes instead of sample. Tubes suffered a vigorous agitation and were placed on a pre-warmed incubator for $2 \mathrm{~h}$ at $150{ }^{\circ} \mathrm{C}$. After the digestion, tubes were taken from the incubator and placed in the dark to cool down to room temperature. Lastly, the absorbance of the tubes was read at $600 \mathrm{~nm}$ with a colorimeter. COD concentrations were then calculated based on a calibration curve performed with glucose standards.

Acetate, propionate, butyrate, valerate and lactate, xylose, and glucose were measured by HPLC. For this, $650 \mu \mathrm{L}$ of each sample were filtered using centrifuge tube filters with a cellulose acetate membrane, $0.2 \mu \mathrm{m}$ pore size at $8000 \mathrm{rpm}$ for $20 \mathrm{~min}$. Samples were then injected (Auto-sampler HITACHI L-2200, Hitachi, Ltd., Chiyoda, Japan) in an ion exchange column Aminex HPX-87H (Bio-Rad, 
Hercules, CA, USA) at $40{ }^{\circ} \mathrm{C}$ (Oven Gecko-2000, CIL Cluzeau, Sainte-Foy-la-Grande, France), and analyzed by a refractive index detector (HITACHI L-2490, Hitachi, Ltd., Chiyoda, Japan). The eluent $0.01 \mathrm{~N} \mathrm{H}_{2} \mathrm{SO}_{4}$ was pumped at a flow rate of $0.6 \mathrm{~mL} / \mathrm{min}$ (HITACHI L-2130 pump, Hitachi, Ltd., Chiyoda, Japan) at room temperature. The eluent was prepared with milli-Q water and filtered with a cellulose acetate membrane, $0.22 \mu \mathrm{m}$ pore size. The concentrations of sugars and SCOAs in $\mathrm{g} / \mathrm{L}$ were determined by comparison with the calibration curves of each analyzed compound obtained using standards of known concentrations. The standards concentrations were within the range of the expected concentrations of the analytes: 0.15 to $3.00 \mathrm{~g} / \mathrm{L}$ for lactate and valerate; 0.20 to $4.00 \mathrm{~g} / \mathrm{L}$ for propionate and butyrate; 0.25 to $5.00 \mathrm{~g} / \mathrm{L}$ for glucose, xylose, and acetate.

LS were measured according to Restolho et al. [24]. The absorbance of samples was measured in a spectrophotometer (Shimadzu UVmini-1240, Shimadzu Corp., Kyoto, Japan) at $273 \mathrm{~nm}$, after a dilution of 1:400. LS concentration was calculated using the Beer-Lambert law with a molar attenuation coefficient of $7.41 \mathrm{~g} / \mathrm{cm}$ [25].

\subsection{Calculations}

The concentrations of SCOAs, sugars, and biomass were determined by volume of mixed liquor and were converted from $\mathrm{g} / \mathrm{L}$ to $\mathrm{g} C \mathrm{COD} / \mathrm{L}$ using conversion factors that represent the mass $(\mathrm{g})$ of oxygen required to oxidize $1 \mathrm{~g}$ of compound based on the oxidation reactions for each compound. The overall oxidation equation is represented below.

$$
\text { a compound }+\mathrm{bO}_{2} \rightarrow \mathrm{c} \mathrm{CO} 2+\mathrm{d} \mathrm{H}_{2} \mathrm{O}+\mathrm{e} \mathrm{NH}_{3}
$$

In which $a, b, c, d$, and e represent the stoichiometric coefficients of the equation. Therefore, the conversion factor (cf) was calculated according with the following Equation:

$$
\operatorname{cf}\left(\mathrm{gO}_{2} / \mathrm{g}\right)=\frac{\mathrm{b} \times \mathrm{M}\left(\mathrm{O}_{2}\right)}{\mathrm{a} \times \mathrm{M}(\text { compound })}
$$

The conversion factors were $1.07 \mathrm{~g} \mathrm{O}_{2} / \mathrm{g}$ for glucose, xylose, lactate, and acetate; $1.51 \mathrm{~g} \mathrm{O}_{2} / \mathrm{g}$ for propionate; $1.82 \mathrm{~g} \mathrm{O}_{2} / \mathrm{g}$ for butyrate; and $2.04 \mathrm{~g} \mathrm{O}_{2} / \mathrm{g}$ for valerate. For biomass, an empirical molecular formula of $\mathrm{C}_{5} \mathrm{H}_{7} \mathrm{NO}_{2}$ that corresponded to a conversion factor of $1.42 \mathrm{~g} \mathrm{O}_{2} / \mathrm{g}$ for biomass was assumed [19].

Additionally, acidification degrees (ADs) were calculated for the fermentative process. The total acidification degree $\left(\mathrm{AD}_{\text {Total }}\right)$ represents the amount of substrate consumed to produce SCOAs considering all the organic matter entering the reactor Equation (3). The sugars acidification degree $\left(\mathrm{AD}_{\text {Sugars }}\right)$ represents the amount of sugars consumed to produce SCOAs, considering the xylose and glucose fed to the reactor Equation (4). These calculations were performed as percentages.

$$
\begin{gathered}
\mathrm{AD}_{\text {Total }}(\% \mathrm{COD})=\frac{[\mathrm{SCOAs}]_{\text {out }}-[\mathrm{SCOAs}]_{\text {in }}}{\mathrm{COD}_{\text {In }}} \\
\mathrm{AD}_{\text {Sugars }}(\% \mathrm{COD})=\frac{[\mathrm{SCOAs}]_{\text {out }}-[\mathrm{SCOAs}]_{\text {in }}}{\mathrm{COD}_{\text {Sugars in }}} \times 100
\end{gathered}
$$

\section{Results and Discussion}

The CSTR inoculated with an aerobic consortium was operated with a HRT of 1.76 days. A short SRT was chosen since short SRTs were already observed to promote the growth of acidogenic organisms comparatively to methanogens, usually presenting low growth rates [2]. Moreover, the use of an aerobic population as inoculum was also based on the fact that methanogens are strict anaerobes and acidogenic bacteria are facultative anaerobes $[11,26]$. Consequently, the conditions imposed were expected to favor the acidogenic population. The initial COD concentration of the CSTR feed $(20.8 \mathrm{~g}$ COD/L) 
was chosen considering preliminary assays of acidogenic fermentation of HSSL (data not shown) and taking into account the COD and LS concentrations of HSSL obtained after the chemical pre-treatment (266 g COD/L and $190 \mathrm{~g} / \mathrm{L}$, respectively). This corresponded to an organic load rate of $11.8 \mathrm{~g} \mathrm{COD/L}$ day. Temperature was kept in the mesophilic range $\left(30^{\circ} \mathrm{C}\right)$, because at this value the process can occur efficiently without major energy requirements [2]. Finally, $\mathrm{pH}$ was monitored but not controlled along the operational period of the CSTR. This can be advantageous at an industrial level, considering that lower amounts of chemicals are required and no extra equipment for $\mathrm{pH}$ control is needed, thus reducing operation costs. This would also be beneficial for the process scale-up.

\subsection{Acidogenic Fermentation of HSSL}

The variation of SCOA composition during the CSTR operational period, which lasted about 88 days, as well as of the main sugars, glucose and xylose, is shown in Figure 1.

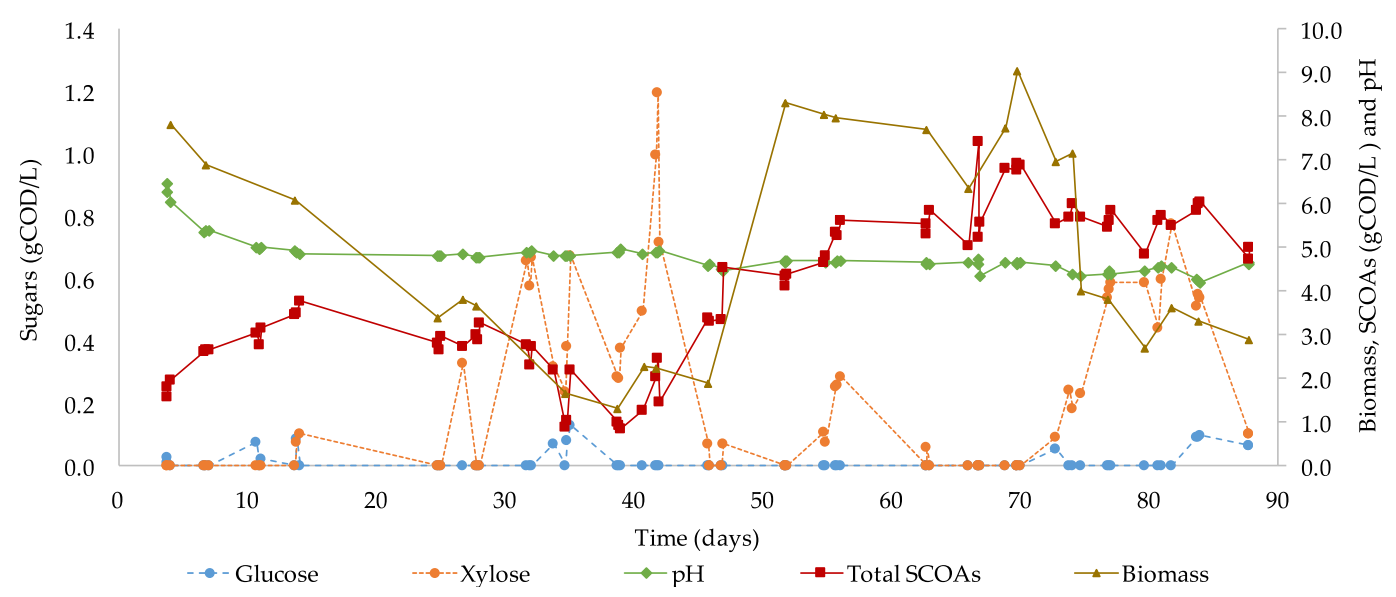

Figure 1. Evolution of short-chain organic acids (SCOAs), sugars, biomass, and $\mathrm{pH}$ variation during the fermentative process. COD: carbon oxygen demand.

At the beginning of the operational period, the CSTR lost a significant amount of biomass, reaching the lowest value $(1.3 \mathrm{~g}$ COD/L) on the 39 th day. The observed loss of biomass probably resulted from the operational conditions imposed. The short SRT would not allow for the survival of slow-growing bacteria. Additionally, the obligate aerobes initially present in the inoculum were probably washed out from the system due to the selective pressure that resulted from the anaerobic conditions imposed. Then, from the 46th day, a quick increase was observed in the following five days, and then it stabilized between 7.0 and $9.0 \mathrm{~g} \mathrm{COD/L}$ until the 74th day, when it started to decrease again. A same pattern of biomass concentration was observed by Fernández-Morales et al. [26] during the acclimatization of conventional aerobic activated sludge to obtain an enriched acidogenic culture.

Most days, glucose was exhausted while xylose was not. This could show a preference for glucose over xylose by the culture. It is known that the metabolic pathway for glucose conversion to SCOAs is simpler than for xylose, with fewer enzymatic steps. Glucose enters directly in the glycolysis step, producing pyruvic acid, from which SCOAs are synthetized [10]. On the other hand, xylose needs to be converted to the intermediary D-xylulose-5-phosphate and go through pentose phosphate pathway (most commonly) to finally arrive in glycolysis and then be converted to pyruvate, and consequently, into SCOAs [10,27,28]. Moreover, Temudo et al. [10] verified that xylose catabolism was more efficient than glucose under anaerobic conditions, since more ATP was generated per mole of substrate. However, when authors compared the ATP-utilization for biomass production, biomass growth from xylose was less efficient than from glucose [10].

During the first 15 days of operation, a gradual increase of SCOAs production was observed, and then it stabilized until the 30th day. A drastic decrease in SCOA production was observed between 
days 30 and 40, which could be a consequence of the increase of glucose and xylose concentrations observed in the reactor. The minimum value of total SCOA concentration $(0.86 \mathrm{~g}$ COD/L $)$ was obtained on the 39th day (Figures 1 and 2). The decrease in SCOA concentration could be a consequence of the lowest biomass concentration observed on this day in the CSTR (Figure 1), suggesting that the culture was still unstable. The $\mathrm{pH}$ also fluctuated during this period, probably due to the verified instability. Generally, throughout the CSTR operational period, a higher concentration of SCOAs in the reactor effluent corresponded to a lower amount of sugars. An increase in the amount of sugars in the reactor effluent coincided with lower SCOAs production.

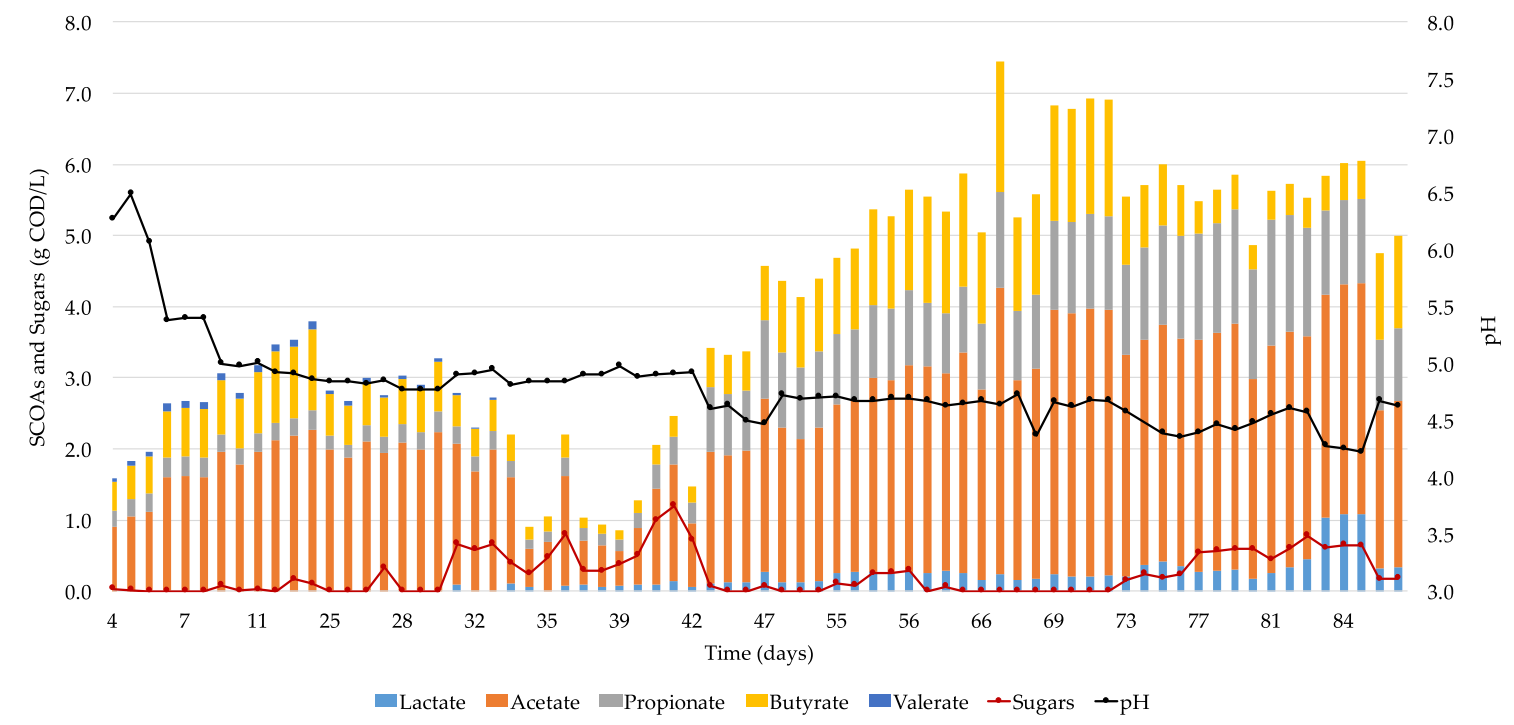

Figure 2. SCOA production profile, sugars, and $\mathrm{pH}$ evolution throughout fermentation time.

Total SCOA maximum concentration was achieved on day 71, and corresponded to an average value of $7.0 \mathrm{~g} \mathrm{COD} / \mathrm{L}$, which was comparable to the values reported in the literature. For instance, Bengtsson et al. [29] tested the AF of four industrial wastes in batch mode with $\mathrm{pH}$ controlled at 6.00. The maximum SCOA concentration obtained was $3.96 \mathrm{~g}$ COD/L using a waste derived from a paper mill [29]. Additionally, Silva et al. [8] studied the AF of eight organic streams in batch experiments, and the maximum SCOA concentration obtained was $3.37 \mathrm{~g}$ COD/L for cheese whey. Lastly, Jie et al. [30] tested different $\mathrm{pH}$ values and their impact on $\mathrm{AF}$ of excess sludge, and observed the highest SCOA concentration for $\mathrm{pH}$ 10.0, $3.16 \mathrm{~g}$ COD/L. Moreover, the SCOA concentration obtained seemed to be related not only to the conditions imposed during the AF process, but also to the AF potential of the waste used. In this way, despite the presence of inhibitory components, and due to the sugar content, HSSL bears a significant AF potential, comparable to the wastes tested in the literature $[8,29,30]$.

The concentrations of sugars and SCOAs were the parameters chosen to evaluate the stability of the microbial population. More stable sugars and SCOA concentrations- $-3.8 \pm 0.25$ and $5.5 \pm 0.84 \mathrm{~g}$ COD/L, respectively-were obtained from day 45 onward. A pseudo-stationary state was considered to have been reached after this day, meaning that after inoculation, the system required 44 days to adapt to substrate and conditions imposed (Table 1). The reduction in the biomass concentration at the beginning of the process could be responsible for the long adaptation time. Moreover, the presence of known bacterial inhibitors in HSSL such as gallic acid, pyrogallol, and furfural, as reviewed by Pereira et al. [22], could affect the SCOAs and biomass concentrations obtained, and consequently contribute to the long adaptation time [26,31]. An introduction of a pre-adaptation step in batch mode could accelerate the adaptation of the MMC to HSSL. 
Table 1. Main results from the acidogenic fermentation of hardwood sulfite spent liquor (HSSL).

\begin{tabular}{|c|c|c|c|c|c|c|c|c|c|c|}
\hline \multirow[t]{2}{*}{ Parameters } & \multirow{2}{*}{$\begin{array}{l}\text { Time } \\
\text { (Day) }\end{array}$} & \multicolumn{2}{|c|}{ Sugars Consumed * } & \multirow{2}{*}{$\begin{array}{l}\text { SCOAs * }^{*} \\
\text { (g COD/L) }\end{array}$} & \multicolumn{5}{|c|}{ SCOAs Profile (\% COD) * } & \multirow{2}{*}{$\mathrm{AD} *(\%)$} \\
\hline & & g COD/L & $(\%)$ & & Lactate & Acetate & Propionate & Butyrate & Valerate & \\
\hline Operation & $0-88$ & $3.8 \pm 0.29$ & $94 \pm 7.2$ & $4.0 \pm 1.76$ & $3.9 \pm 3.91$ & $59 \pm 6.8$ & $17 \pm 6.8$ & $19 \pm 6.5$ & $1.0 \pm 1.3$ & $20 \pm 9.0$ \\
\hline PSS & $46-88$ & $3.8 \pm 0.25$ & $94 \pm 6.3$ & $5.5 \pm 0.84$ & $5.7 \pm 3.91$ & $53 \pm 3.2$ & $22 \pm 4.2$ & $19 \pm 7.5$ & $0.0 \pm 0.00$ & $28 \pm 4.3$ \\
\hline
\end{tabular}

${ }^{*}$ mean values \pm standard deviation. AD: acidification degree. PSS: Pseudo-steady state

\subsection{Short-chain Organic Acids (SCOAs) Production}

As stated previously, $\mathrm{pH}$ was not controlled during the process, and its variation is shown in Figure 2. The SCOA concentration was maximal during a period with $\mathrm{pH}$ values lower than 5.0. Previous studies indicated that this range of $\mathrm{pH}$ values generally results in very low yields of SCOA production $[2,29]$. By not controlling the $\mathrm{pH}$ in the CSTR and letting it remain under 5.0, methanogens would be washed out from the system, resulting in a possible way to improve SCOA concentration. Consequently, this could be a way to control the methanogenic population without adding inhibitors for methanogenic bacteria.

Acetate, propionate, and butyrate were the SCOAs obtained in higher concentrations during the operational period. During the PSS, $3.0 \pm 0.53 \mathrm{~g}$ COD/L of acetate, $1.2 \pm 0.24 \mathrm{~g}$ COD/L of propionate, and $1.0 \pm 0.45 \mathrm{~g} \mathrm{COD} / \mathrm{L}$ of butyrate were produced. Acetate was the SCOA with highest concentration most of the time, followed by propionate (Figure 2). The presence of these SCOAs in the mixed liquor was already expected since they are usually the main products of AF [2]. Chang et al. [32] verified that those were the most common SCOAs generated after the AF of diverse complex substrates that included food wastes, pig and chicken manure, rice straw, and corn stover [32].

Propionate and butyrate concentrations appeared to be somehow inversely related, and dependent on the $\mathrm{pH}$ (Figure 3). For $\mathrm{pH}$ lower than 4.6, propionate seemed to dominate over butyrate, and the opposite could be observed for higher $\mathrm{pH}$ values. This is in agreement with the literature that reports different metabolic pathways for the production of the two acids, suggesting the existence of two different types of populations competing for the carbon source $[29,30,33]$.

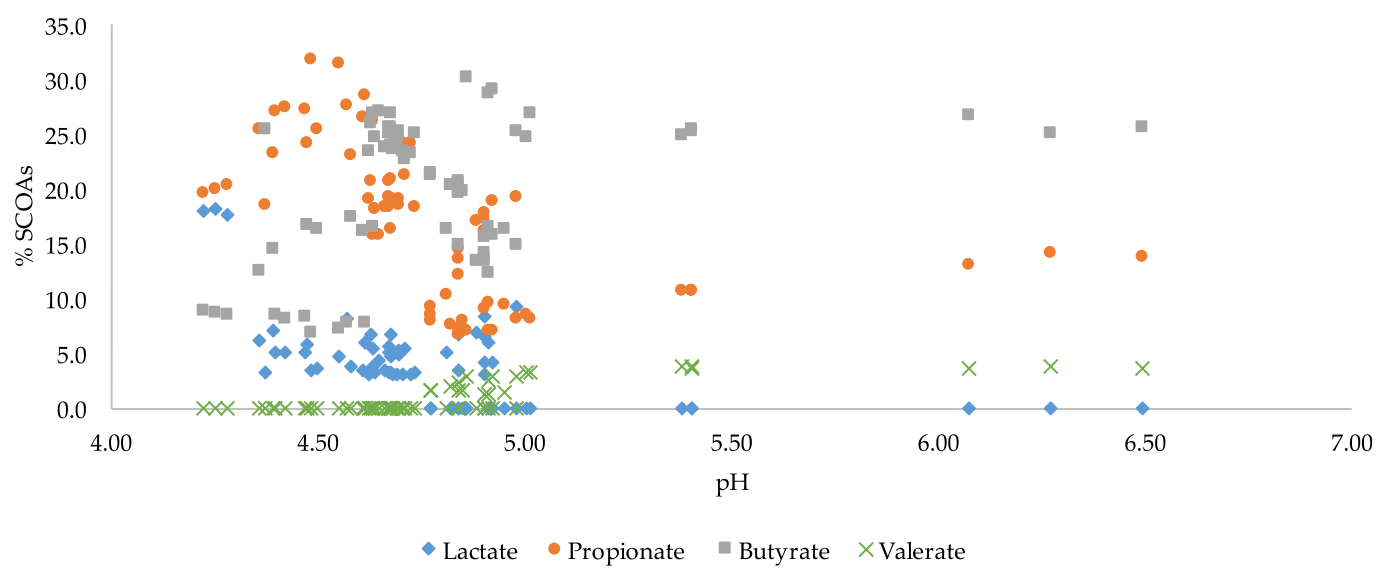

Figure 3. Short-chain Organic Acids (SCOAs) concentrations versus $\mathrm{pH}$ values obtained during the continuous stirred tank reactor (CSTR) operation.

The concentrations of valerate and lactate also seemed to be related to $\mathrm{pH}$ values (Figure 3). During the first 32 days, valerate concentration reached its maximum value of $0.11 \mathrm{~g} \mathrm{COD} / \mathrm{L}$. Experimental data showed that valerate production occurred when $\mathrm{pH}$ values were higher than 4.8 , especially at the beginning of the CSTR operational period. Then, $\mathrm{pH}$ values decreased over time (probably as a result of the increase of SCOAs concentration over time), and the concentration of 
valerate decreased. This fact is consistent with the results obtained by Lim et al. [34] for AF of food waste after testing three $\mathrm{pH}$ values $(5.0,5.5,6.0)$ in a semi-continuous reactor with once-a-day feeding and draw-off. At pH 5.0, valerate production was not detected [34]. Regarding lactate, it was only detected when $\mathrm{pH}$ values lower than 5.0 (Figure 3). These findings were in agreement with some AF studies that observed lactate production under similar conditions [34-36]. Thus, lactate achieved a maximum concentration at $\mathrm{pH} 4.3$ after 84 days of fermentation. The maximum lactate obtained corresponded to $18 \%$ of the total SCOAs (Figure 2 ).

The $\mathrm{pH}$ seemed to be a crucial parameter in the definition of the SCOAs profile during AF, despite being a direct consequence of SCOAs production. It probably influenced the selection of different acidogenic populations in the MMC and their ability to produce different SCOAs. The influence of $\mathrm{pH}$ on the type of SCOAs obtained has already been shown by Albuquerque et al. [37]. Moreover, a tight relationship between $\mathrm{pH}$ and type of SCOAs produced should be achieved in future works for HSSL, since tailoring the distribution of SCOAs produced based on $\mathrm{pH}$ is essential when using the SCOAs mixtures as substrates in bioprocesses such as PHAs production by MMC [37].

\subsection{Acidification Degree}

Acidification degrees (ADs) relatively to the total COD, $\mathrm{AD}_{\text {total, }}$ and to the main sugars xylose and glucose, $\mathrm{AD}_{\text {sugars, }}$ were determined along the CSTR operational period. $\mathrm{AD}_{\text {total }}$ had a maximum of $36 \%$ on day 71, which corresponded to the maximum value of SCOA concentration obtained. The reason for the relatively low $\mathrm{AD}_{\text {total }}$ could be explained by the majority of the COD present in the feed being constituted by phenolic compounds, LS, and other recalcitrant compounds, which are more difficult to biodegrade than sugars by the microbial population [38].

The maximum $\mathrm{AD}_{\text {sugars }}$ obtained was $175 \%$ on day 71 . This value shows that besides xylose and glucose, other compounds present in the HSSL were probably used for SCOAs production. These compounds probably included other monomeric sugars such as rhamnose, arabinose, mannose, or galactose [39], usually below the detection limit of HPLC due to the dilution applied to samples before analysis. Assuming the data provided by Caima-Indústria de Celulose SA, the HSSL after the chemical pre-treatment would have 1.36, 1.14, 2.28, $2.28 \mathrm{~g}$ COD/L of rhamnose, arabinose, mannose, and galactose, respectively. Taking these values into consideration and assuming their total consumption, the $\mathrm{AD}_{\text {TotalSugars }}$ would be $154 \%$. This result means that besides sugars, some phenolic components or even LS would be used for SCOAs production. Hence, it would be interesting to analyze the evolution of the different components of HSSL in more detail to understand which compounds were being consumed to produce SCOAs.

In order to improve the $\mathrm{AD}_{\text {Total, }}$ higher HRT values should be imposed to the CSTR to assess whether the most recalcitrant compounds of HSSL_LS and phenolics—could be acidified. The possibility of maximizing the amount of components of HSSL acidified not only increases the concentration of SCOAs obtained, but also decreases the amount of possible microbial inhibitors, which favors the utilization of the fermented stream in further bioprocesses.

\section{Conclusions}

A CSTR was operated for 88 days in order to acidify part of the organic components of HSSL. The system took about 45 days to reach a pseudo-steady state under the operational conditions imposed. On day 71, a maximum SCOA concentration of 7.0 g COD/L was obtained, which corresponded to an $\mathrm{AD}_{\text {Total }}$ of $36.0 \%$. The experimental results showed that it was possible to perform the acidification of HSSL and obtain SCOA by inoculating the CSTR with an aerobic MMC. The use of an aerobic inoculum and leaving the $\mathrm{pH}$ uncontrolled could be responsible for the significant SCOA production. Future studies should focus on testing higher HRTs, different reactor conformation (e.g., moving bed biofilm reactor), and controlling the $\mathrm{pH}$ to different values in order to improve the concentration of SCOAs and the amount of HSSL components consumed. Finally, microbiological studies should be performed in order to understand how the microbial community changed over time. 
Acknowledgments: This work was developed within the scope of the project CICECO-Aveiro Institute of Materials (Ref. FCT UID/CTM/50011/2013), financed by national funds through the FCT/MEC and when appropriate co-financed by FEDER under the PT2020 Partnership Agreement. Authors acknowledge Eng. A. Prates from CAIMA-Indústria de Celulose S.A., Constância, Portugal for HSSL. Diogo Queirós thanks FCT for his PhD grant (SFRH/BD/87758/2012).

Author Contributions: Diogo Queirós and Luísa S. Serafim conceived and designed the experiments; Diogo Queirós, Rita Sousa and Susana Pereira performed the experiments; Diogo Queirós, Rita Sousa and Luísa S. Serafim analyzed the data. Diogo Queirós and Rita Sousa wrote the paper.

Conflicts of Interest: The authors declare no conflict of interest.

\section{References}

1. Fava, F.; Totaro, G.; Diels, L.; Reis, M.; Duarte, J.; Carioca, O.B.; Poggi-Varaldo, H.M.; Ferreira, B.S. Biowaste biorefinery in Europe: Opportunities and research \& development needs. New Biotechnol. 2015, 32, 100-108.

2. Lee, W.S.; Chua, A.S.M.; Yeoh, H.K.; Ngoh, G.C. A review of the production and applications of waste-derived volatile fatty acids. Chem. Eng. J. 2014, 235, 83-99. [CrossRef]

3. Koutinas, A.A.; Vlysidis, A.; Pleissner, D.; Kopsahelis, N.; Lopez Garcia, I.; Kookos, I.K.; Papanikolaou, S.; Kwan, T.H.; Lin, C.S.K. Valorization of industrial waste and by-product streams via fermentation for the production of chemicals and biopolymers. Chem. Soc. Rev. 2014, 43, 2587-2627. [CrossRef] [PubMed]

4. Frison, N.; Katsou, E.; Malamis, S.; Oehmen, A.; Fatone, F. Development of a novel process integrating the treatment of sludge reject water and the production of polyhydroxyalkanoates (PHAs). Environ. Sci. Technol. 2015, 49, 10877-10885. [CrossRef] [PubMed]

5. Shen, L.; Hu, H.; Ji, H.; Cai, J.; He, N.; Li, Q.; Wang, Y. Production of poly(hydroxybutyrate-hydroxyvalerate) from waste organics by the two-stage process: Focus on the intermediate volatile fatty acids. Bioresour. Technol. 2014, 166, 194-200. [CrossRef] [PubMed]

6. Woo Park, G.; Fei, Q.; Jung, K.; Chang, H.N.; Kim, Y.-C.; Kim, N.; Choi, J.; Kim, S.; Cho, J. Volatile fatty acids derived from waste organics provide an economical carbon source for microbial lipids/biodiesel production. Biotechnol. J. 2014, 9, 1536-1546. [CrossRef] [PubMed]

7. Elefsiniotis, P.; Wareham, D.G.; Smith, M.O. Use of volatile fatty acids from an acid-phase digester for denitrification. J. Biotechnol. 2004, 114, 289-297. [CrossRef] [PubMed]

8. Silva, F.C.; Serafim, L.S.; Nadais, H.; Arroja, L.; Capela, I. Acidogenic fermentation towards valorisation of organic waste streams into volatile fatty acids. Chem. Biochem. Eng. Q. 2013, 27, 467-476.

9. Ke, S.; Shi, Z.; Fang, H.H.P. Applications of two-phase anaerobic degradation in industrial wastewater treatment. Int. J. Environ. Pollut. 2005, 23, 65-80. [CrossRef]

10. Temudo, M.F.; Mato, T.; Kleerebezem, R.; van Loosdrecht, M.C.M. Xylose anaerobic conversion by open-mixed cultures. Appl. Microbiol. Biotechnol. 2009, 82, 231-239. [CrossRef] [PubMed]

11. Visvanathan, C.; Abeynayaka, A. Developments and future potentials of anaerobic membrane bioreactors (AnMBRs). Membr. Water Treat. 2012, 3, 1-23. [CrossRef]

12. De Aquino, S.F.; Chernicharo, C.A.L. Acúmulo de ácidos graxos voláteis (AGVs) em reatores anaeróbios sob estresse: causas e estratégias de controle. Eng. Sanit. E Ambient. 2005, 10, 152-161. [CrossRef]

13. Queirós, D.; Rossetti, S.; Serafim, L.S. PHA production by mixed cultures: A way to valorize wastes from pulp industry. Bioresour. Technol. 2014, 157, 197-205. [CrossRef] [PubMed]

14. Queirós, D.; Fonseca, A.; Lemos, P.C.; Serafim, L.S. Long-term operation of a two-stage polyhydroxyalkanoates production process from hardwood sulphite spent liquor. J. Chem. Technol. Biotechnol. 2016, 91, $2480-2487$. [CrossRef]

15. Jiang, J.; Zhang, Y.; Li, K.; Wang, Q.; Gong, C.; Li, M. Volatile fatty acids production from food waste: Effects of $\mathrm{pH}$, temperature, and organic loading rate. Bioresour. Technol. 2013, 143, 525-530. [CrossRef] [PubMed]

16. Jankowska, E.; Chwiałkowska, J.; Stodolny, M.; Oleskowicz-Popiel, P. Effect of pH and retention time on volatile fatty acids production during mixed culture fermentation. Bioresour. Technol. 2015, 190, $274-280$. [CrossRef] [PubMed]

17. Scoma, A.; Bertin, L.; Fava, F. Effect of hydraulic retention time on biohydrogen and volatile fatty acids production during acidogenic digestion of dephenolized olive mill wastewaters. Biomass Bioenergy 2013, 48, 51-58. [CrossRef] 
18. Miron, Y.; Zeeman, G.; van Lier, J.B.; Lettinga, G. The role of sludge retention time in the hydrolysis and acidification of lipids, carbohydrates and proteins during digestion of primary sludge in CSTR systems. Water Res. 2000, 34, 1705-1713. [CrossRef]

19. Dogan, E.; Demirer, G.N. Volatile fatty acid production from organic fraction of municipal solid waste through anaerobic acidogenic digestion. Environ. Eng. Sci. 2009, 26, 1443-1450. [CrossRef]

20. Rueda, C.; Calvo, P.A.; Moncalián, G.; Ruiza, G.; Coz, A. Biorefinery options to valorize the spent liquor from sulfite pulping. J. Chem. Technol. Biotechnol. 2015, 90, 2218-2226. [CrossRef]

21. Zygmunt, B.; Banel, A. Formation, occurrence and determination of volatile fatty acids in environmental and related samples. In Proceedings of the 3rd WSEAS International Conference on Energy Planning, Energy Saving, Environmental Education, Renewable Energy Sources, Waste Management, Tenerife, Spain, 2009; pp. 476-481.

22. Pereira, S.R.; Ivanuša, S.; Evtuguin, D.V; Serafim, L.S.; Xavier, A.M.R.B. Biological treatment of eucalypt spent sulphite liquors: A way to boost the production of second generation bioethanol. Bioresour. Technol. 2012, 103, 131-135. [CrossRef] [PubMed]

23. Clesceri, L.S.; Greenberg, A.E.; Eaton, A.D. Standard Methods for the Examination of Water and Wastewater, 20th ed.; American Public Health Association, 1998. Available online: https:/ /www.standardmethods.org/ (accessed on 1 March 2015).

24. Restolho, J.A.; Prates, A.; de Pinho, M.N.; Afonso, M.D. Sugars and lignosulphonates recovery from eucalyptus spent sulphite liquor by membrane processes. Biomass Bioenergy 2009, 33, 1558-1566. [CrossRef]

25. Xavier, A.M.R.B.; Correia, M.F.; Pereira, S.R.; Evtuguin, D.V. Second-generation bioethanol from eucalypt sulphite spent liquor. Bioresour. Technol. 2010, 101, 2755-2761. [CrossRef] [PubMed]

26. Fernández-Morales, F.J.; Villaseñor, J.; Infantes, D. Modeling and monitoring of the acclimatization of conventional activated sludge to a biohydrogen producing culture by biokinetic control. Int. J. Hydrog. Energy 2010, 35, 10927-10933. [CrossRef]

27. Jeffries, T.W. Advances in biochemical engineering/biotechnology. In Pentoses and Lignin; Fieehter, A., Ed.; Springer: Berlin/Heidelberg, Germany, 1983; pp. 1-32.

28. Prakasham, R.S.; Brahmaiah, P.; Sathish, T.; Sambasiva Rao, K.R.S. Fermentative biohydrogen production by mixed anaerobic consortia: Impact of glucose to xylose ratio. Int. J. Hydrog. Energy 2009, 34, 9354-9361. [CrossRef]

29. Bengtsson, S.; Hallquist, J.; Werker, A.; Welander, T. Acidogenic fermentation of industrial wastewaters: Effects of chemostat retention time and $\mathrm{pH}$ on volatile fatty acids production. Biochem. Eng. J. 2008, 40, 492-499. [CrossRef]

30. Jie, W.; Peng, Y.; Ren, N.; Li, B. Volatile fatty acids (VFAs) accumulation and microbial community structure of excess sludge (ES) at different pHs. Bioresour. Technol. 2014, 152, 124-129. [CrossRef] [PubMed]

31. Cohen, A.; Gemert, J.M.V.; Zoetemeyer, R.J.; Breure, A.M. Main characteristics and stoichiometric aspects of acidogenesis of soluble carbohydrate containing wastewater. Process Biochem. 1984, 19, 282-286.

32. Chang, H.N.; Kim, N.-J.; Kang, J.; Jeong, C.M. Biomass-derived volatile fatty acid platform for fuels and chemicals. Biotechnol. Bioprocess Eng. 2010, 15, 1-10. [CrossRef]

33. Horiuchi, J.-I.; Shimizu, T.; Tada, K.; Kanno, T.; Kobayashi, M. Selective production of organic acids in anaerobic acid reactor by $\mathrm{pH}$ control. Bioresour. Technol. 2002, 82, 209-213. [CrossRef]

34. Lim, S.J.; Kim, B.J.; Jeong, C.M.; Choi, J.D.; Ahn, Y.H.; Chang, H.N. Anaerobic organic acid production of food waste in once-a-day feeding and drawing-off bioreactor. Bioresour. Technol. 2008, 99, 7866-7874. [CrossRef] [PubMed]

35. Gouveia, A.R.; Freitas, E.B.; Galinha, C.F.; Carvalho, G.; Duque, A.F.; Reis, M.A. Dynamic change of pH in acidogenic fermentation of cheese whey towards polyhydroxyalkanoates production: Impact on performance and microbial population. New Biotechnol. 2017, 37, 108-116. [CrossRef] [PubMed]

36. Itoh, Y.; Tada, K.; Kanno, T.; Horiuchi, J.I. Selective production of lactic acid in continuous anaerobic acidogenesis by extremely low pH operation. J. Biosci. Bioeng. 2012, 114, 537-539. [CrossRef] [PubMed]

37. Albuquerque, M.G.E.; Eiroa, M.; Torres, C.; Nunes, B.R.; Reis, M.A.M. Strategies for the development of a side stream process for polyhydroxyalkanoate (PHA) production from sugar cane molasses. J. Biotechnol. 2007, 130, 411-421. [CrossRef] [PubMed] 
38. Jantsch, T.G.; Angelidaki, I.; Schmidt, J.E.; Braña de Hvidsten, B.E.; Ahring, B.K. Anaerobic biodegradation of spent sulphite liquor in a UASB reactor. Biores. Technol. 2002, 84, 15-20. [CrossRef]

39. Pereira, S.R.; Portugal-Nunes, D.J.; Evtuguin, D.V.; Serafim, L.S.; Xavier, A.M.R.B. Advances in ethanol production from hardwood spent sulphite liquors. Process Biochem. 2013, 48, 272-282. [CrossRef]

(C) 2017 by the authors. Licensee MDPI, Basel, Switzerland. This article is an open access article distributed under the terms and conditions of the Creative Commons Attribution (CC BY) license (http:/ / creativecommons.org/licenses/by/4.0/). 